\title{
Pre-treatment antinuclear antibody positivity, therapeutic efficacy and persistence of biologics in rheumatoid arthritis
}

\section{Pozitivitatea anticorpilor antinucleari anterioară tratamentului, eficacitatea terapeutică şi persistenţa terapiei biologice în poliartrita reumatoidă}

\author{
Cătălin Codreanu ${ }^{1,2}$, Corina Mogoșan ${ }^{1}$, Claudiu Costinel Popescu ${ }^{1, *}$, Simona \\ Rednic $^{3}$, Horațiu Popovici ${ }^{4}$, Magda Pârvu ${ }^{5}$, Daniela Opriş ${ }^{6,7}$, Ruxandra Ionescu ${ }^{6,7}$ \\ 1 "Dr. Ion Stoia" Clinical Center of Rheumatic Diseases, Bucharest, Romania, " Carol Davila" \\ University of Medicine and Pharmacy, Bucharest, Romania, ${ }^{3}$ County Emergency Hospital Cluj- \\ Napoca, Romania; "Iuliu Haţieganu” University of Medicine and Pharmacy, Cluj-Napoca, Romania, \\ ${ }^{4}$ Rheumatology Department of Mures County Hospital, Romania; University of Medicine and \\ Pharmacy of Targu Mures, Romania, ${ }^{5}$ Rheumatology Department of Clinical Hospital Colentina, \\ Bucharest, Romania, 'Internal Medicine and Rheumatology Department of "Sfânta Maria" Clinical \\ Hospital, Bucharest, Romania, " "Carol Davila” University of Medicine and Pharmacy, Bucharest,
}

Romania

\begin{abstract}
Introduction: Rheumatoid factor (RF) and anti-citrullinated protein antibodies (ACPA) are poor prognostic factors in rheumatoid arthritis (RA). The therapeutic implication of antinuclear antibody (ANA) positivity in RA is still debated. The study aims to evaluate ANA positivity as a prognostic factor for the therapeutic response to biologics in RA.

Methods: observational study; data were gathered from the Romanian Registry of Rheumatic Diseases which comprises all biological-treated RA patients in Romania. We included only RA patients who were tested for ANA before initiating biologics.

Results: A number of 740 RA patients were included (72.4\% treated with TNF- $\alpha$ blockers, $27.6 \%$ with rituximab). Compared to ANA-negative patients, ANA-positive patients (26.9\%) had: a higher disease activity score (DAS28) prior to biologics, at the time of treatment switch and after the observation period; lower drug persistence $(p<0.001$ for all tests). Multiple linear regressions showed that ANA positivity is a significant predictor of the current value of DAS28, independently of the presence of RF and/or ACPA $(p<0.05)$.

Conclusion: ANA positivity in RA patients before starting biologics may be a poor prognosis factor for efficacy and drug persistence. Further studies are needed to confirm these observations.
\end{abstract}

Keywords: rheumatoid arthritis; antinuclear antibodies; biological therapy.

* Corresponding author: Claudiu Costinel Popescu, "Ion Stoia" Clinical Hospital, Rheumatology, $5^{\text {th }}$ Thomas Masaryk, Bucharest, Romania, e-mail: dr.reumatologie@gmail.com 


\section{Rezumat}

Introducere: Factorul reumatoid (FR) şi anticorpii anti-CCP sunt factori de pronostic negativ cunoscuţi în tratamentul poliartritei reumatoide (PR). Semnificaţia terapeutică a anticorpilor antinucleari (ANA) în PR este neclară. Studiul îşi propune să evalueze pozitivitatea ANA ca factor de prognostic pentru răspunsul terapeutic la biologice în PR. Metode: Studiu observaţional; datele au fost obţinute din Registrul Român de Boli Reumatice, care cuprinde toţi pacienţii cu PR din România trataţi cu biologice. Au fost incluşi în studiu numai pacienţii cu PR la care s-au testat ANA înaintea initierii terapiei biologice.

Rezultate: Au fost incluşi în studiu 740 de pacienţi cu PR (72,4\% trataţi cu blocante de TNF- $\alpha$, 27,6\% trataţi cu rituximab). In comparaţie cu pacienţii fără ANA, pacienţii cu ANA pozitivi aveau ( $p<0,001$ pentru toate comparaţiile): DAS28 semnificativ mai mare înaintea iniţierii biologicului, la momentul schimbării biologicului şi la finalul perioadei de observație; persistenţă a biologicului semnificativ mai mică. Regresiile liniare multiple au arătat că pozitivitatea ANA este un factor predictiv semnificativ pentru valoarea DAS28, independent de prezenţa FR şi/sau a anticorpilor anti-CCP $(p<0,05)$.

Concluzii: Pozitivitatea ANA la pacienţii cu PR anterioară iniţierii terapiei biologice ar putea fi un factor de prognostic negativ pentru eficacitatea şi persistenţa tratamentului. Este nevoie de studii suplimentare pentru a confirma această observaţie.

Cuvinte cheie: poliartrita reumatoidă; anticorpi antinucleari;tratament biologic.

Received: 15 $5^{\text {th }}$ October 2015; Accepted: $3^{\text {th }}$ April 2016; Published: $10^{\text {th }}$ May 2016.

\section{Introduction}

Antinuclear antibodies (ANA) are a well-known test of autoimmunity, either systemic (e.g. systemic lupus erythematosus - SLE, rheumatoid arthritis - RA etc.) or organ-specific (e.g. Hashimoto's thyroiditis, autoimmune hepatitis etc.). Their low specificity is due to their presence both in non-autoimmune conditions such as infections (e.g. hepatitis $\mathrm{C}$ virus (1), human immunodeficiency virus (2) etc.), cancer (3), vascular disease $(4,5)$, drug-induced (including infliximab (6)) and in normal individuals (7), especially in female and geriatric patients. Immunoassays have identified different types of ANA (e.g. double-stranded DNA, anti-histones, U1-RNP, Sm, Ro, La, Scl-70 etc.), which along with the staining pattern (e.g. diffuse, peripheral, speckled, nucleolar, centromeric) increase the usefulness of ANA in clinical practice, allowing physicians to discern between different rheumatologic autoimmune diseases.

The prevalence of ANA positivity in RA varies greatly in the literature and the titers of ANA are generally lower in RA than in autoimmune connective diseases such as SLE and systemic sclerosis (8). In RA, circulating ANA usually react with histones, but there are no routine tests available for clinical practice (9), and their appearance seems to be associated with a mutation of the tumor necrosis factor (TNF) receptor gene (10). On one hand, advanced or prolonged disease (8), and on the other hand young age of RA onset ( $<40$ years) (11) are associated with a higher prevalence of ANA positivity in women. ANA-positive RA patients used more drugs prior to diagnosis (12), presented an increased level of pain, had a higher prevalence of vasculitis and of other extra-articular manifestations (13) and presented adverse events caused by disease modifying anti-rheumatic drugs (DMARDs).

The therapeutic target in RA is achieving remission or low disease activity (LDA) (14). Among the known poor prognostic factors are positive titers of anti-citrullinated protein antibodies (ACPA) and rheumatoid factors (RF) (15). The amount of evidence for the clinical significance and the therapeutic implications of ANA positivity in RA patients is limited. In this context, this study aims to evaluate the implications of ANA 
positivity, as a prognostic factor, in the therapeutic response to biologic therapy in RA measured by the disease activity score (DAS28).

\section{Methods}

This was a cross-sectional observational study on an adult cohort of RA patients treated with biological DMARDs (bDMARDs) in routine clinical practice and registered in 2014 in the electronic national database: the Romanian Registry of Rheumatic Diseases (RRRD).

Upon inclusion in the RRRD, all patients gave a written informed consent. Patients had to fulfill the following criteria in order to receive bDMARD therapy: a) RA diagnosed by a rheumatologist according to the European League Against Rheumatism - American College of Rheumatology (EULAR/ACR) 2010 criteria (16); b) either high disease activity - HDA (DAS28 > 5.1) irrespective of disease duration or early RA $(<2$ years $)$ with moderate disease activity - MDA (DAS28 > 3.2) and with at least 5 poor prognosis factors (age $<45$ years; RF and/or ACPA 10 times the upper limit of normal - ULN; erythrocyte sedimentation rate - ESR > $50 \mathrm{~mm} / \mathrm{h}$ or $\mathrm{C}$ reactive protein - CRP $>5$ times the ULN; a swollen joint count above 5; erosions on X-rays, ultrasound or magnetic resonance imaging; Health Assessment Questionnaire - HAQ $>1.5$; extra-articular manifestations), both with at least 5 swollen and/or tender joints and at least 2 of the following 3 criteria: morning stiffness above 60 minutes, ESR $>28 \mathrm{~mm} / \mathrm{h}, \mathrm{CRP}>3$ times the ULN; c) lack of response to at least 2 conventional synthetic DMARDs (csDMARDs) used for 12 weeks each; d) no known contraindications of bDMARDs. Using the clinical and laboratory measures, RA activity was assessed using DAS28, which is a composite score based on the number of tender joints, the number of swollen joints, ESR and the visual analog scale for patient-reported general health (17). The DAS28 values were used to classify the patients into the following categories: remission (DAS28 $\leq 2.6)$; LDA (DAS28 = 2.6-3.2); MDA (DAS28 $=3.2-5.1)$ and HDA (DAS28 > 5.1).

For the purpose of this study we included only those RA patients who were tested for the presence of ANA before initiating any bDMARD (only adalimumab, etanercept, infliximab, rituximab were subsidized in the study time frame). The RRBR does not require ANA testing, but it can record this information if the attending physician has indicated this test for a certain patient. ANA titers were determined by enzyme-linked immunosorbent assay in different laboratories across the country. The ANA test was considered positive if its titer was at least 2 times the upper limit of normal of the particular laboratory.

Data distribution normality was assessed using descriptive statistics, normality, stem-andleaf plots and the Lillefors corrected Kolmogorov-Smirnov test. Nominal data were expressed as "absolute value (percentage of group)" and were studied using cross-tabs with $\chi^{2}$. Normally distributed scale data were reported as "mean \pm standard deviation" and their correlations and differences were assessed using parametric tests: bivariate Pearson and partial correlations of 2 scale variables; $t$ tests and ANOVA for differences of scale variables in groups with 2 (e.g. ANA) or more categories (e.g. RA disease activity). Non-normally distributed data were reported "median (minimum - maximum)" and their correlations and differences were assessed using nonparametric tests: bivariate Spearman and Mann Whitney tests. Post-hoc analysis was used to determine which categories of multi-level nominal variables (DAS28 activity classes) led to significant $\chi^{2}$ tests according to ANA status: adjusted standardized residuals were calculated and transformed to $\chi^{2}$ values and for each $\chi^{2}$ value, $p$ values were calculated and compared to the 
Bonferoni adjusted $\mathrm{p}$ value $(0.00625)$ in order to avoid a type 1 error. Multiple linear and logistic regression models were calculated in order to assess the independent predictive capacity of variables. The assessment of the differences of bDMARD survival distribution according to ANA status was done using the Kaplan-Meier method. All tests were considered significant if $p<0.05$ and were done using Statistical Package for the Social Sciences v.17 (SPSS Inc., Chicago, USA, 2008) for Windows.

\section{Results}

\section{General characteristics}

A number of 740 RA patients were included in the study, with a mean age of $56.5 \pm 12.59$ years (Table 1), a median RA duration of 11 (2-36) years (established disease) and a mean baseline DAS28 of $5.09 \pm 2.35$. The age of onset and the disease duration of ANA-positive women did not differ significantly from those of ANA-negative women $(p>0.1)$. Overall, $72.4 \%$ of pa-

Table 1. Characteristics of the group $(n=740)$

\begin{tabular}{|c|c|}
\hline \multicolumn{2}{|l|}{ General characteristics } \\
\hline age (years) & $56.5 \pm 12.6$ \\
\hline females & $625(84.5 \%)$ \\
\hline weight $(\mathrm{kg})$ & $69.9 \pm 14.1$ \\
\hline urban residence & $491(66.4 \%)$ \\
\hline age retired & $272(36.7 \%)$ \\
\hline \multicolumn{2}{|l|}{$R A$ characteristics } \\
\hline RA work disabled & $281(38.0 \%)$ \\
\hline RA duration (years)* & $11(2-36)$ \\
\hline ANA positive & $199(26.9 \%)$ \\
\hline RF positive & $664(89.8 \%)$ \\
\hline ACPA positive & $237(37 \%)$ \\
\hline current csDMARD & $276(37.3 \%)$ \\
\hline current glucocorticoids & $698(94.3 \%)$ \\
\hline bDMARD switch & $163(22.0 \%)$ \\
\hline global bDMARD persistence (months)* & $13(1-124)$ \\
\hline bDMARD persistence after switch (months)* & $12(1-92)$ \\
\hline pre-bDMARD DAS28 & $5.1 \pm 2.4$ \\
\hline current DAS28 & $2.9 \pm 1.4$ \\
\hline remission & $387(52.3 \%)$ \\
\hline low disease activity & $141(19.1 \%)$ \\
\hline moderate disease activity & $149(20.1 \%)$ \\
\hline high disease activity & $63(8.5 \%)$ \\
\hline \multicolumn{2}{|c|}{$\begin{array}{l}\text { Note: normally distributed scale variables (unmarked) are reported as "mean } \pm \text { SD", non-normally } \\
\text { distributed scale variables }(*) \text { are reported as "median (minimum - maximum)", while frequencies are } \\
\text { reported as "absolute value (percentage of total)". }\end{array}$} \\
\hline \multicolumn{2}{|c|}{$\begin{array}{l}\text { Abbreviations: } A C P A \text { - anti-citrullinated protein antibodies; } A N A \text { - antinuclear antibodies; b/csDMARD - biologic/conven- } \\
\text { tional synthetic disease-modifying antirheumatic drugs; } D A S \text { - disease activity score; } R A-\text { rheumatoid arthritis; } R F-\text { rheu- } \\
\text { matoid factors; } S D \text { - standard deviation. }\end{array}$} \\
\hline
\end{tabular}


tients were treated with TNF- $\alpha$ blockers, while $27.6 \%$ with rituximab. The patients had a very high rate of glucocorticoid treatment $(94.3 \%)$. The most frequent initial bDMARD was etanercept (Figure 1), followed by adalimumab, infliximab and rituximab. At the end of the observation period, the proportion of patients treated with TNF- $\alpha$ blockers decreased, while the proportion of patients treated with rituximab increased (Figure 1), reflecting the clinical judgment of switching a case of non-responsiveness to another mode of action. During follow-up, $163(22.0 \%)$ of subjects required a switch of bDMARD therapy: 12 (7.4\% of switchers) were in remission, 0 ( $0 \%$ of switchers) had LDA, 32 (19.6\% of switchers) had MDA and 119 (73.0\% of switchers) had HDA. Also, 528 (71.4\%) patients achieved the therapeutic target of remission or LDA: 165 (31.3\%) were already in remission or LDA at the beginning of the observation period, $112(21.2 \%)$ had MDA and $251(47.5 \%)$ had HDA.

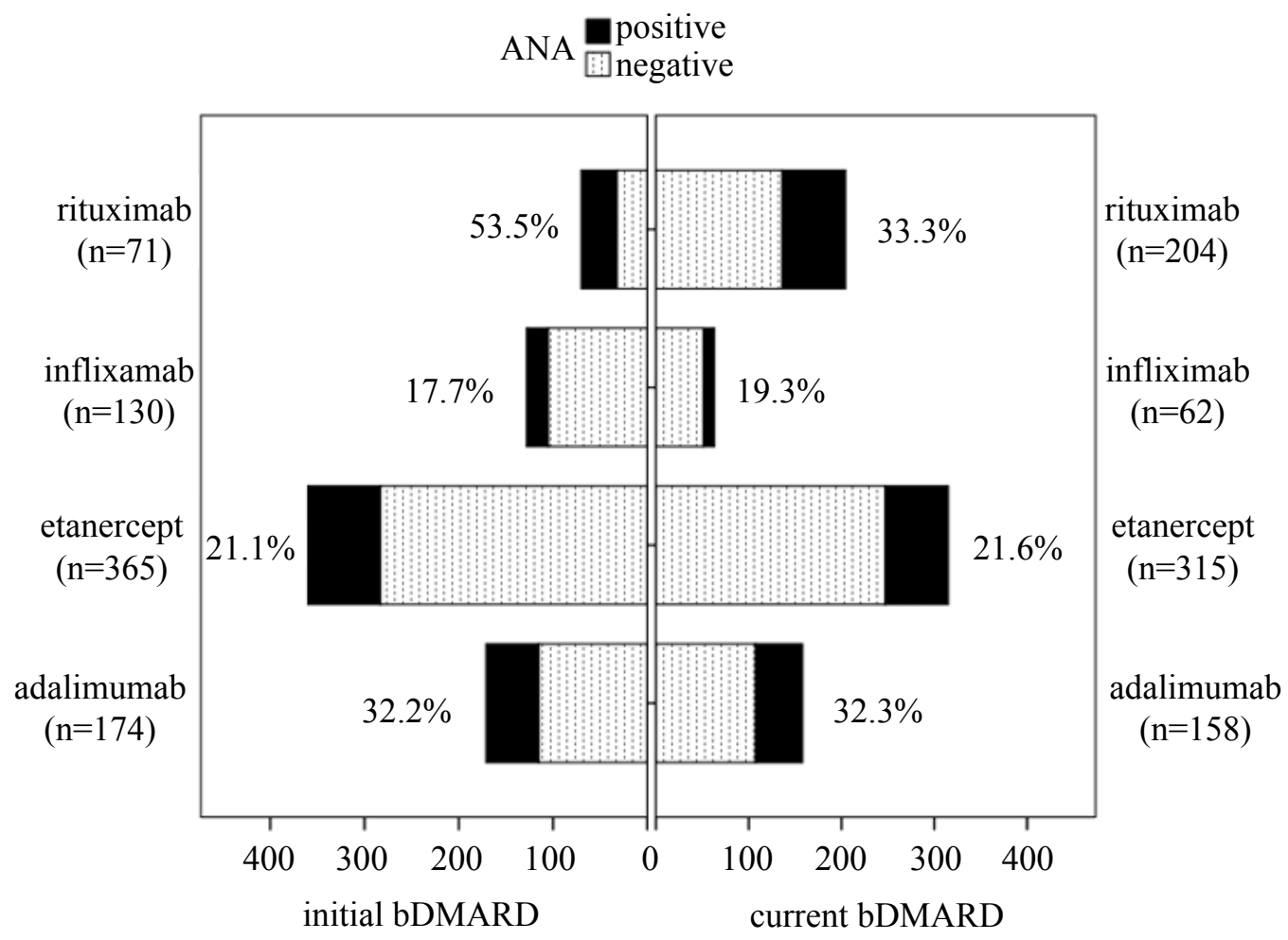

Figure 1. The distribution of bDMARD treatment in the sample $(n=740)$

The distribution of bDMARD treatment in the sample $(n=740)$ at the beginning and at the end of the observation period, along with ANA positivity. The percentages represent the fraction of ANA positive patients in each bDMARD subgroup at each moment of observation (for example 71 patients had rituximab as the initial bDMARD and 53.5\% of them were ANA positive). One patient who had rituximab as initial bDMARD had no current bDMARD, being in drug-free remission.

Abbreviations: ANA - antinuclear antibodies; bDMARD - biologic disease modifying anti-rheumatic drug. 


\section{ANA-positive patients}

At baseline (prior to bDMARDs), 199 (26.9\%) patients were ANA-positive, 664 (89.8\%) were RF-positive and 237 (37\%) were ACPA-positive. The 199 ANA-positive patients displayed the following serology overlap: 97 (48.7\%) were RF and ACPA-positive, 21 (10.6\%) were RF and ACPA-negative, 73 (36.7\%) were RF-positive ACPA-negative and $8(4 \%)$ were RF-negative ACPA-positive.

The differences of ANA positivity and DAS28 activity classes were non-significant between males and females $(\mathrm{p}>0.1)$. Compared to ANA-negative RA patients $(\mathrm{n}=541 ; 73.1 \%)$, those with positive ANA titers $(\mathrm{n}=199 ; 26.9 \%)$ had a higher toll of disease activity (Table 2, Figure 2), as reflected by a significantly higher DAS28 at three different time points: pre-bDMARD, bDMARD switch and current (final)
DAS28. In order to exclude the influence of disease severity on this observation, we extracted from the sample all the ANA-positive patients with initial MDA and HDA $(n=156)$ and all the ANA-negative patients with initial MDA and HDA ( $\mathrm{n}=324)$. Upon testing, the ANA-positive patients with initial MDA and HDA had a significantly higher current (final) DAS28 compared to the ANA-negative patients with initial MDA and HDA $(3.52 \pm 1.72$ compared to $3.08 \pm 1.47$; $\mathrm{p}=$ 0.004). In order to exclude the influence of ANA positivity, we extracted from the sample all the ANA-positive patients with initial MDA and HDA $(\mathrm{n}=156)$ and all the ANA-positive patients with initial LDA and remission $(n=44)$. Upon testing, the ANA-positive patients with initial MDA and HDA had a significantly higher current (final) DAS28 compared to the ANA-positive patients with initial LDA and remission (3.52 \pm 1.72 com-

Table 2. Differences according to ANA status

\begin{tabular}{|c|c|c|c|}
\hline & ANA & & \\
\hline & $\begin{array}{l}\text { negative } \\
(\mathrm{n}=541)\end{array}$ & $\begin{array}{l}\text { positive } \\
(\mathrm{n}=199)\end{array}$ & $p$ \\
\hline age (y) & $53.9 \pm 8.8$ & $52.8 \pm 10.8$ & 0.437 \\
\hline RA duration $(y)^{*}$ & $12(2-36)$ & $10(2-32)$ & 0.019 \\
\hline weight $(\mathrm{kg})$ & $70.1 \pm 14.5$ & $72.3 \pm 10.3$ & 0.449 \\
\hline retirement duration $(\mathrm{y})$ & $10.9 \pm 6.4$ & $10.9 \pm 7.6$ & 0.715 \\
\hline pre-bDMARD DAS28 & $5.81 \pm 1.84$ & $6.61 \pm 1.58$ & $<0.001$ \\
\hline current DAS28 & $2.75 \pm 1.31$ & $3.32 \pm 1.61$ & $<0.001$ \\
\hline$\Delta \mathrm{DAS} 28$ & $0.23 \pm 1.51$ & $-0.23 \pm 1.13$ & 0.003 \\
\hline treatment duration of initial bDMARD $(\mathrm{m})^{*}$ & $16(1-124)$ & $8(1-113)$ & $<0.001$ \\
\hline DAS28 at switch & $4.64 \pm 1.52$ & $5.33 \pm 1.56$ & 0.039 \\
\hline treatment duration of switched bDMARD $(\mathrm{m})^{*}$ & $12(1-92)$ & $12(1-47)$ & 0.923 \\
\hline
\end{tabular}

Notes:

- normally distributed scale variables (unmarked) are reported as "mean $\pm \mathrm{SD}$ ", non-normally distributed scale variables $(*)$ are reported as "median (minimum - maximum)";

- $\triangle$ DAS28 was calculated by subtracting from the current DAS28 the value of DAS28 from 6 months earlier;

- $\mathrm{p}$ values represent the significance of $\mathrm{t}$ tests (unmarked) or of Mann Whitney tests (*).

Abbreviations: ANA - antinuclear antibodies; bDMARD - biologic disease-modifying antirheumatic drugs; DAS - disease activity score; $m$ - months; $R A$ - rheumatoid arthritis; $S D$ - standard deviation; $y=$ years. 


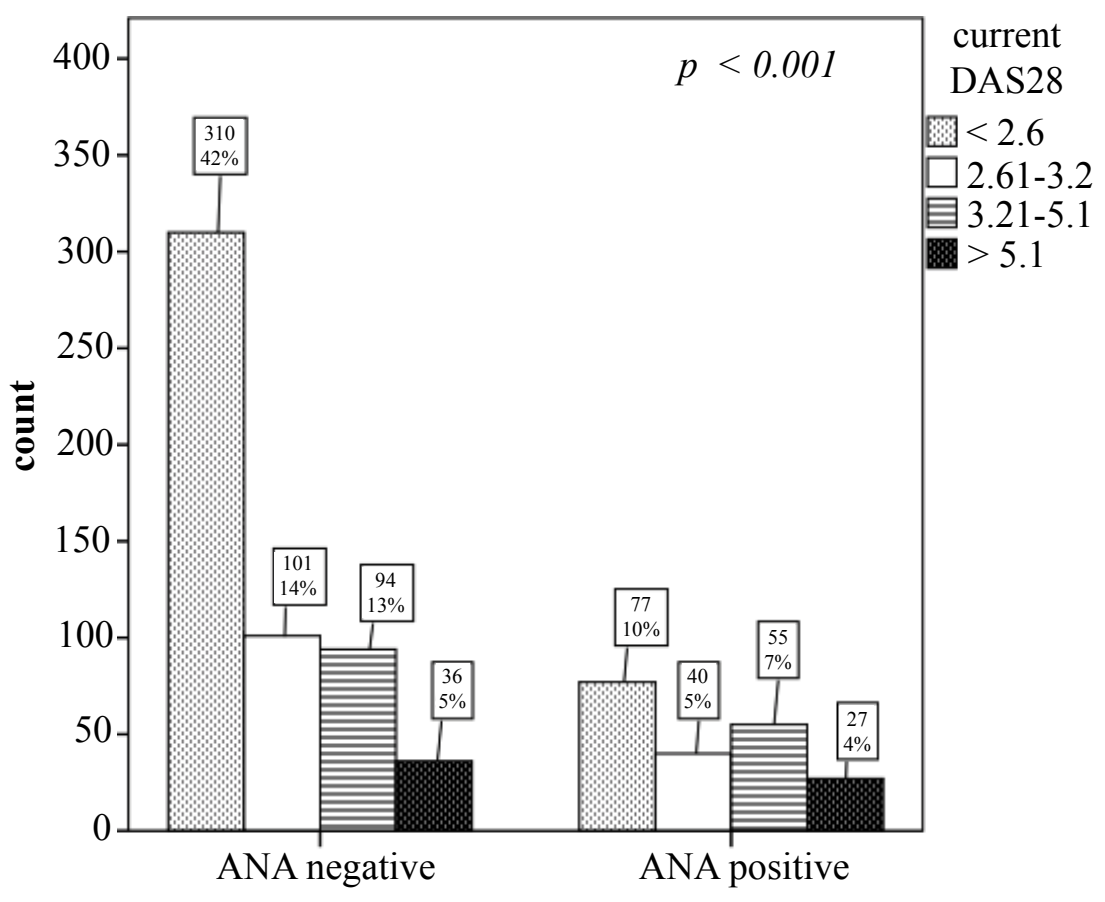

Figure 2. Disease activity classes according to ANA status

( $p$ values represent the significance level of the $\chi 2$ test). Abbreviations: ANA - antinuclear antibodies; bDMARD - biologic disease-modifying antirheumatic drugs.

pared to $2.61 \pm 0.81 ; \mathrm{p}=0.001)$.

Generally, $75.9 \%$ of ANA-negative patients and only $58.8 \%$ of ANA-positive patients reached the therapeutic target of remission or LDA $(p<0.001)$. Similarly, $41.2 \%$ of ANA-positive patients and only $24.0 \%$ of ANA-negative patients had MDA or HDA ( $\mathrm{p}<0.001)$. Post-hoc analysis of the ANA-DAS28 class association showed notable results: $13.6 \%$ of ANA-positive patients were in HDA, significantly higher than those without ANA (6.7\%; $p=0.003)$; similarly, 27.6\% of ANA-positive patients were in MDA, significantly higher than those without ANA (17.4\%; $\mathrm{p}=0.002)$; conversely, $38.7 \%$ of ANA-positive patients were in remission, significantly lower than those without ANA $(57.3 \% ; \mathrm{p}<0.001)$; the proportion of ANA-positive patients in LDA did not differ significantly from the proportion of ANA-negative patients in LDA $(p=0.689)$.
Disease activity and treatment prediction by ANA

A multiple linear regression model was calculated to predict the current DAS28 based on the following independent variables: age (years), gender (" 0 " for "female", "1" for "male"), weight (kg), ANA, RF and ACPA status (" 0 " for "negative", " 1 " for "positive"), disease duration (years) and csDMARD treatment (" 0 " for "no", " 1 " for "yes"). The model was significant $(\mathrm{F}(8,740)=11.7, \mathrm{p}<0.001$, $\left.\mathrm{R}^{2}=0.113\right)$ and it showed that ANA is a significant predictor of the current DAS28 (Figure 3A). A binary logistic regression was performed to assess the effects of the above mentioned independent variables on the likelihood that the patients have high disease activity (" 0 " for "remission and LDA", "1" for "MDA and HDA"). The model was significant $\left(\chi^{2}(8)=52.3, \mathrm{p}<0.001, \mathrm{R}^{2}=0.098\right)$ and it showed that ANA-positive patients are two times 
A

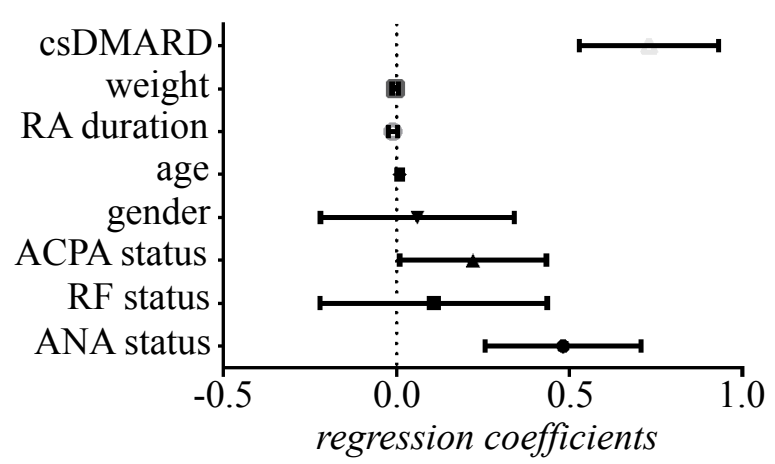

B

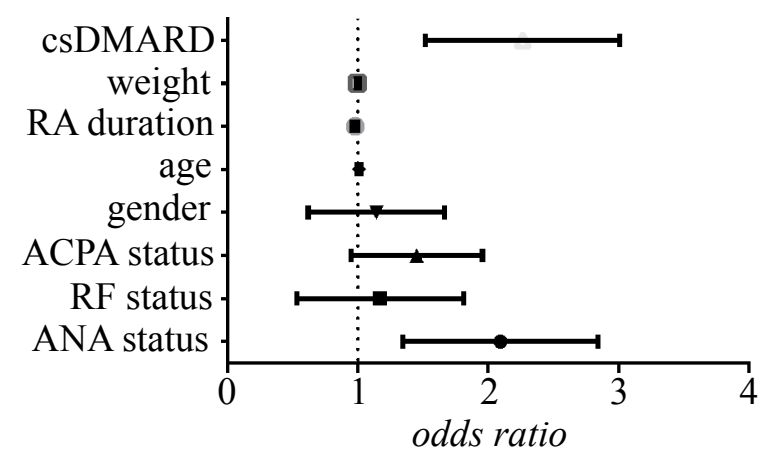

Figure 3. Prediction of DAS28 value and classes

Panel A plots the linear regression coefficients (with their CI) of the independent variables used to predict DAS28 values. Panel B plots the odds ratios from the logistic regression model used to predict DAS28 classes. Both models show that positive ANA status is a significant predictor of high DAS28.

Abbreviations: ACPA - anti-citrullinated protein antibodies; ANA - antinuclear antibodies; b/csDMARD - biologic/conventional synthetic disease-modifying antirheumatic drugs; $C I$ - confidence interval; DAS - disease activity score; RA - rheumatoid arthritis; $R F$ - rheumatoid factors.

more likely to be found in the upper DAS28 classes (Figure 3B).

Overall bDMARD persistency (the duration of therapy under one drug) had a median duration of 13 (1-124) months for those without a switch. The bDMARD persistence in ANA- positive patients had a median duration of 8 (1-113) months, significantly lower than the one of the ANA-negative group, which had a median duration of $16(1-124)$ months ( $<<0.001$; Figure 4).

\section{Discussion}

ANA positivity varies greatly $(10-70 \%)$ in different cohorts $(8,12)$ and the frequency we observed $(27 \%)$ is consistent with the literature. Our cohort had relatively high mean age (56 years) and relatively high disease duration (a median of 11 years; Table 1), both factors being associated with an increase in the prevalence of ANA positivity. Therefore the results are best interpreted in the context of middle aged RA patients with established disease. Testing ANA status in an observational study which would include only early RA patients (18) (for example before the appearance of bone erosions or with disease duration lower than 2 years) would further substantiate the relationship between this serological marker and treatment outcomes. Our data did not confirm the cited longer disease duration (8) and lower age of onset in ANA-positive RA women compared to ANA-negative women (9) and there were no data regarding the number of drugs used, pain level, extra-articular manifestations and adverse events related to DMARDs to compare with the cited literature $(12,13)$.

We observed that ANA-positive RA patients have higher disease activity (before and after bDMARD treatment - Table 2) and lower bDMARD persistency (Figure 4) compared to ANA-negative patients. Therefore, the following question arises: does disease severity or treatment resistance explain the higher disease activity and lower bDMARD persistency associated 


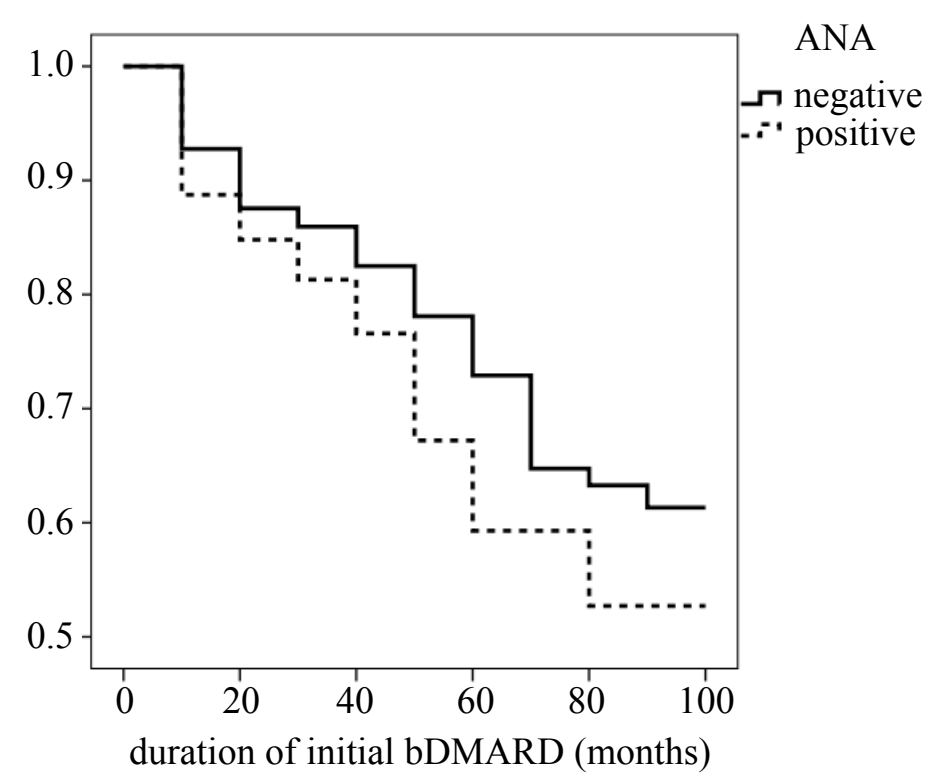

Figure 4. Survival of the first bDMARD until switch according to ANA status

Kaplan-Meier survival study of the first bDMARD until switch according to ANA status $(\chi 2=23.2 ; \mathrm{p}<0.001)$. The median duration of the initial bDMARD in ANA-negative patients, 16 (1 - 124) months, was significantly higher than that of ANA-positive patients, 8 (1-113) months ( $\mathrm{p}<0.001$; Mann Whitney test).

Abbreviations: ANA - antinuclear antibodies; bDMARD - biologic disease-modifying antirheumatic drugs.

with ANA positivity? Unfortunately, there are only few data regarding the significance of ANA in RA. Caspi et al. (12) found that ANA-positive patients complained of arthralgia more often than ANA-negative patients, which is consistent with our finding of a higher DAS28 in ANA-positive patients, but the number of involved joints were similar in both groups, which is not confirmed by our findings. However, studying RA with disease duration lower than 5 years, Amaya-Amaya et al. (19) observed that non-erosive RA is associated with ANA positivity, which is strong evidence for disease severity not being responsible for the higher disease activity and lower bDMARD persistency we observed in our study. In favor of treatment resistance, our data showed that among patients with initial pre-DMARD
MDA and HDA, those who were ANA-positive had a significantly higher current (final) DAS28 than those who were ANA-negative. This observation is consistent with the hypothesis of an ANA-positive drug resistant RA phenotype. Further proof is brought by Rodriguez-Carrio et al. (20), who observed that ANA positivity is associated with a lower count of angiogenic $\mathrm{T}$ cells, which are involved in endothelial repair, knowing that TNF- $\alpha$ blockers and rituximab are associated with an improvement on endothelial function $(21,22)$. There is evidence of methotrexate resistance associated with ANA positivity (23) and therefore bDMARDs resistance associated with ANA positivity is plausible, but since they have different mechanisms of action, a prospective comparative study would provide 
further information. In favor of disease severity, we observed that among ANA-positive patients, those with initial pre-DMARD MDA and HDA had a significantly higher current (final) DAS28 than those with initial pre-DMARD LDA and remission. However, since this is a non-controlled observational study, treatment regimens administrated before the start of the observation may influence the above mentioned findings. A controlled prospective observational study would provide further information.

The possible mechanisms of our observation are numerous. ANA are a hallmark of SLE and some of these antibodies (e.g. anti-double stranded DNA antibodies) are involved in the pathogenesis of the disease and its phenotypes $(24,25)$. However, no ANA has been pathogenically linked to RA (26). Considering our data, it is possible that ANA identify a serological phenotype of RA with a drug resistance in terms of achieving the therapeutic target of DAS28-defined remission and LDA. Rather a consequence of the disease than a pathogenic factor, these ANA may initiate and sustain joint inflammation by tissue deposition and immune complex formation. A first step in discerning this effect would be the antibody specificity characterization of ANA subclasses in RA.

There are several study limitations which may interfere with the correct interpretation of the results. The fact that the study was not controlled (variation of clinical and laboratory methods) could generate a significant error. There were no data regarding the staining pattern of ANA and its titers were determined by different laboratories. There were no radiographic data regarding RA joint damage.

\section{Conclusions}

ANA positivity before initiating the biological therapy may be a poor prognostic factor for the therapeutic efficacy, as well as for the drug per- sistence. Further studies are needed to confirm these observations.

\section{Conflicts of interest}

The authors declare no conflicts of interest.

\section{References}

1. Clifford BD, Donahue D, Smith L, Cable E, Luttig B, Manns M, et al. High prevalence of serological markers of autoimmunity in patients with chronic hepatitis C. Hepatology. 1995;21(3):613-9. DOI: 10.1016/02709139(95)90507-3 DOI: 10.1002/hep.1840210302.

2. Bonnet F, Pineau JJ, Taupin JL, Feyler A, Bonarek M, de WS, et al. Prevalence of cryoglobulinemia and serological markers of autoimmunity in human immunodeficiency virus infected individuals: a cross-sectional study of 97 patients. JRheumatol. 2003;30(9):2005-10.

3. Imran A, Neelam F, Tariq M. Incidence of circulating antinuclear antibodies in cancer patients. Indian JMedSci. 2003;57(3):113-6.

4. Qadan LR, Ahmed AA, Abdel-Jalil S, Al-Bader MA. Significance of antinuclear antibodies and rheumatoid factor in patients with advanced peripheral arterial disease. MedPrincPract. 2010;19(3):192-5. DOI: 10.1159/000273071.

5. Rich S, Kieras K, Hart K, Groves BM, Stobo JD, Brundage BH. Antinuclear antibodies in primary pulmonary hypertension. JAmCollCardiol. 1986;8(6):130711. DOI: $10.1016 / \mathrm{s} 0735-1097(86) 80301-1$.

6. Yukawa N, Fujii T, Kondo-Ishikawa S, Yoshifuji H, Kawabata D, Nojima T, et al. Correlation of antinuclear antibody and anti-double-stranded DNA antibody with clinical response to infliximab in patients with rheumatoid arthritis: a retrospective clinical study. Arthritis ResTher. 2011;13(6):R213. DOI: 10.1186/ar3546.

7. Nisihara R, Kubis MM, Rodrigues PC, Skare T, Mocelin V, Utiyama S. Antinuclear antibodies and rheumatoid factor positivity in healthy elderly adults: a cross-sectional study in 336 individuals. JAmGeriatrSoc. 2013;61(11):2044-6. DOI: 10.1111/jgs.12533.

8. Nishimura S, Nishiya K, Hisakawa N, Chikazawa H, Ookubo S, Nakatani K, et al. Positivity for antinuclear antibody in patients with advanced rheumatoid arthritis. Acta MedOkayama. 1996;50(5):261-5. 
9. Muzellec Y, Le GP, Jouquan J, Fauquert P, Muller S, Youinou P. Antibodies to histones in rheumatoid arthritis. DiagnClinImmunol. 1988;5(6):326-31.

10. Glossop JR, Dawes PT, Mattey DL. Antinuclear antibodies are associated with tumor necrosis factor receptor I gene polymorphism in patients with rheumatoid arthritis. ClinExpRheumatol. 2011;29(4):609-15.

11. Jacobsen S. Young age of onset is associated with increased prevalence of circulating IgM rheumatoid factor and antinuclear antibodies at presentation in women with rheumatoid arthritis. ClinRheumatol. 2004;23(2):121-2. DOI: 10.1007/s10067-003-0844-9.

12. Caspi D, Elkayam O, Eisinger M, Vardinon N, Yaron M, Burke M. Clinical significance of low titer anti-nuclear antibodies in early rheumatoid arthritis: implications on the presentation and long-term course of the disease. RheumatolInt. 2001;20(2):43-7. DOI: 10.1007/ s002960000073.

13. Young A, Koduri G. Extra-articular manifestations and complications of rheumatoid arthritis. BestPractResClinRheumatol. 2007;21(5):907-27. DOI: 10.1016/j.berh.2007.05.007.

14. Smolen JS, Landewe R, Breedveld FC, Buch M, Burmester G, Dougados $\mathrm{M}$, et al. EULAR recommendations for the management of rheumatoid arthritis with synthetic and biological disease-modifying antirheumatic drugs: 2013 update. AnnRheumDis. 2014;73(3):492-509. DOI: 10.1136/annrheumdis-2013-204573.

15. Jilani AA, Mackworth-Young CG. The role of citrullinated protein antibodies in predicting erosive disease in rheumatoid arthritis: a systematic literature review and meta-analysis. IntJRheumatol. 2015;2015:728610. DOI: $10.1155 / 2015 / 728610$.

16. Aletaha D, Neogi T, Silman AJ, Funovits J, Felson DT, Bingham CO, III, et al. 2010 rheumatoid arthritis classification criteria: an American College of Rheumatology/ European League Against Rheumatism collaborative initiative. AnnRheumDis. 2010;69(9):1580-8. DOI: 10.1002/art.27584 DOI: 10.1136/ard.2010.138461.

17. Prevoo ML, van 't Hof MA, Kuper HH, van Leeuwen MA, van de Putte LB, van Riel PL. Modified disease activity scores that include twenty-eight-joint counts. Development and validation in a prospective longitudinal study of patients with rheumatoid arthritis Arthritis Rheum. 1995;38(1):44-8. DOI: 10.1002/ art. 1780380107 .
18. Innala L, Berglin E, Moller B, Ljung L, Smedby T, Sodergren A, et al. Age at onset determines severity and choice of treatment in early rheumatoid arthritis: a prospective study. Arthritis research \& therapy. 2014;16(2):R94. DOI: 10.1186/ar4540.

19. Amaya-Amaya J, Calixto OJ, Saade-Lemus S, CalvoParamo E, Mantilla RD, Rojas-Villarraga A, et al. Does non-erosive rheumatoid arthritis exist? A cross-sectional analysis and a systematic literature review. Seminars in arthritis and rheumatism. 2015;44(5):489-98. DOI: 10.1016/j.semarthrit.2014.09.006.

20. Rodriguez-Carrio J, Alperi-Lopez M, Lopez P, AlonsoCastro S, Ballina-Garcia FJ, Suarez A. Angiogenic $\mathrm{T}$ cells are decreased in rheumatoid arthritis patients. Annals of the rheumatic diseases. 2015;74(5):921-7. DOI: 10.1136/annrheumdis-2013-204250.

21. Mathieu S, Couderc M, Pereira B, Soubrier M. The effects of TNF-alpha inhibitor therapy on arterial stiffness and endothelial dysfunction in rheumatoid arthritis: a meta-analysis. Seminars in arthritis and rheumatism. 2013;43(3):e1-2. DOI: 10.1016/j.semarthrit.2013.05.005.

22. Hsue PY, Scherzer R, Grunfeld C, Imboden J, Wu Y, Del Puerto G, et al. Depletion of B-cells with rituximab improves endothelial function and reduces inflammation among individuals with rheumatoid arthritis. Journal of the American Heart Association. 2014;3(5):e001267. DOI: $10.1161 /$ JAHA.114.001267.

23. Lima A, Monteiro J, Bernardes M, Sousa H, Azevedo R, Seabra V, et al. Prediction of methotrexate clinical response in Portuguese rheumatoid arthritis patients: implication of MTHFR rs1801133 and ATIC rs4673993 polymorphisms. BioMed research international. 2014;2014:368681. DOI: 10.1155/2014/368681.

24. Sawalha AH, Harley JB. Antinuclear autoantibodies in systemic lupus erythematosus. CurrOpinRheumatol. 2004;16(5):534-40. DOI: $\quad$ 10.1097/01. bor.0000135452.62800.8f.

25. Smeenk RJ. Antinuclear antibodies: cause of disease or caused by disease? Rheumatology(Oxford). 2000;39(6):581-4. DOI: 10.1093/rheumatology/39.6.581.

26. Picerno V, Ferro F, Adinolfi A, Valentini E, Tani C, Alunno A. One year in review: the pathogenesis of rheumatoid arthritis. Clinical and experimental rheumatology. 2015;33(4):551-8. 